\title{
Effect of Black Economic Empowerment on profit and competitiveness of firms in South Africa
}

\author{
Authors: \\ Ewert P.J. Kleynhans \\ Melinda C. Kruger ${ }^{1}$ \\ Affiliations: \\ ${ }^{1}$ School of Economics, \\ North-West University, \\ Potchefstroom Campus, \\ South Africa \\ Correspondence to: \\ Ewert Kleynhans \\ Email: \\ 11289570@nwu.ac.za \\ Postal address: \\ Private Bag X6001, \\ Potchefstroom 2520, \\ South Africa \\ Dates: \\ Received: 08 May 2013 \\ Accepted: 26 Mar. 2014 \\ Published: 17 July 2014 \\ How to cite this article: \\ Kleynhans, E.P.J. \& Kruger, \\ M.C., 2014, 'Effect of Black \\ Economic Empowerment on \\ profit and competitiveness \\ of firms in South Africa', Acto \\ Commercii 14(1), Art. \#200, \\ 10 pages. http://dx.doi. \\ org/10.4102/ac.v14i1.200

\section{Copyright:} \\ (C) 2014. The Authors. \\ Licensee: AOSIS \\ OpenJournals. This work \\ is licensed under the \\ Creative Commons \\ Attribution License.
}

Orientation: The key obstacle hindering optimal profitability levels and competitiveness in firms in South Africa is the application of labour legislation policies and tools aimed at narrowing the income gap between different racial groups and resolving inequality amongst a diverse workforce.

Research purpose: This article determined whether the implementation of a Black Economic Empowerment (BEE) policy by companies has a positive effect on their growth in terms of profits and competitiveness.

Motivation for the study: This study determined whether the implementation of BEE could be profitable for companies.

Research design, approach and method: A quantitative study was undertaken in order to find empirical evidence supporting the relation between high BEE Scores, profitability and competitiveness. The empirical investigation utilised regression analysis, correlations and other methods, based on data between January 2009 and December 2011. The BEE Scorecard was used to obtain BEE scores of the top 50 BEE companies. Thereafter, the top 50 companies' financial information was gathered from the Johannesburg Securities Exchange.

Main findings: The implementation of BEE within companies has a positive effect on profitability, turnover and investment. Numerous factors have, however, been hindering, while other factors enhanced the success of BEE.

Practical/managerial implications: The findings encourage mangers to engage in BEE as it may facilitate higher profits and indicates where labour legislation could be improved.

Contribution/value-add: Value was added through new research determining the effects of BEE and labour legislation on profitability and competitiveness of firms on a micro-level.

\section{Introduction}

This study investigates the effect that labour legislation instruments, in particular Black Economic Empowerment (BEE), have on the economic competitiveness and profitability of firms operating on a micro-level in South Africa. Worldwide, commercial activities are governed by rules and regulations, implemented to determine the course of a country's economic growth. Businesses in the private sector operate in accordance with strategic plans and must adhere to codes of conduct that are set up by different state entities. This holds true for South Africa, as it does anywhere else in the world. That being said, South Africa's colourful political past has ensured that South Africa is quite different from the rest of the world and that labour legislation has taken a step in a new direction.

South African firms operating at a micro-level are currently facing some legislative as well as socio-political obstacles (Antonites 2003:1). The South African government has the unique opportunity to fulfil multiple roles. Porter (1998:184) states that governments, on the one hand, should act as catalysts and challengers in order for firms to boost their aspirations and achieve higher levels of competitiveness and profitability. Stiglitz (2006:15), on the other hand, emphasises that not only economic growth, but also economic development, must play an integral part in the transformation of economies. The Employment Equity Act 55 of 1998 (South Africa 1998, s. 2) expects transformation to be fuelled by the reversal of historical errors and the removal of fundamental labour inequalities in the workforce.

Whilst the South African government performs the role of challenger of firms and nurturer of the nation, the firms operating on a micro-level are facing real and serious threats regarding competitiveness and profitability. These firms not only attempt to balance utilising the workforce to achieve maximum profitability and competitiveness, but also to comply with the South African labour legislation. 
In order to investigate the effect of BEE on the economic competitiveness, investments and profitability of firms, this study will also evaluate the challenges that these policies offer to firms and the possible disadvantages that may impair firms' abilities to succeed in their production-related endeavours. The following section will provide a literature study, including a historical overview, definition and detail on BEE and its elements. This is followed by a report on the empirical investigation done and, finally, a discussion and conclusion.

\section{Literature review}

A question asked frequently by economists is whether or not Black Economic Empowerment, from here on referred to as $\mathrm{BEE}$, is an economic growth medium for the South African economy (e.g. Andrews 2008:34).

The purpose of this literature review is, firstly, to provide the historical background of the research topic. This will set the context of the topic and also contribute to the rationalisation and significance thereof. In order for the empirical assessment to be understood successfully, the literature review will investigate the concept of BEE and its composition, profitability and competitiveness; the sustainability and financing of BEE; the enablers and shortcomings of BEE; and policy instruments utilised to achieve BEE. Hereafter, a critical analysis will be made of the literature to justify the later empirical investigation.

\section{Historical overview}

Employment Equity and Affirmative Action in South Africa commenced during the mid-nineteen nineties (Burger \& Jafta 2010:3-5). The Labour Market Commission's policy framework for Affirmative Action identified certain objectives, with productivity enhancement playing a key role (Labour Market Commission 1996:14).

The Employment Equity Act originated as a Green Paper on Employment Equity in 1996. This Green Paper encouraged organisations to audit their organisational structures and develop equity plans, which ultimately came into existence in the Employment Equity Act 55 of 1998 (South Africa 1998). During 1996, with the simultaneous development of the Employment Equity Act, the South African government introduced the GEAR-initiative, which was based on growth, employment and redistribution, whilst an unemployment rate of 40\% prevailed (Dhanorkar 2010:3). The vast majority of this $40 \%$ consisted of black people and related to largescale poverty. The need for participation of this designated group in economic activity became evident. Certain obstacles, such as a lack of assets and access to capital, were the main hindrances with regard to participation. Black Economic Empowerment was established as part of the developed equity plans of the Employment Equity Act to promote the participation of black people in the economy (Burger \& Jafta 2010:3-5).
During 2003, the outline of the concept of broad-based black economic empowerment (BBBEE) came into existence by means of a policy published by the South African Department of Trade and Industry (DTI) (Burger \& Jafta 2010:8). This published document is known as 'A Strategy for Broad-Based Black Economic Empowerment' (Acemoglu, Gelb \& Robinson 2007:9). This document was the first to pay attention to the so-called generic scorecard, identifying certain weights relative to the elements of BEE (Acemoglu et al. 2007:9).

The Broad-Based Black Economic Empowerment Act 53 of 2003 (hereafter referred to as the 'BEE $A c t$ ') was assented to on 07 January 2004 (Burger \& Jafta 2010:8). The purpose of this $B E E$ Act is to focus on the promotion of black economic empowerment and to confer certain rights and obligations onto the Minister of Trade and Industry in order to establish organs to assist in the aforementioned promotion (South Africa 2003, Preamble to Act).

Codes of Good Practice were then developed and published by the Ministry, to act as a guideline for the overall operational aspects of the BEE strategy in South Africa (Burger \& Jafta 2010:7). After much deliberation and processes of approval, the official state newspaper, the Government Gazette, published the Codes of Good Practice on 09 February 2007 (South Africa 2007). Hereafter, a generic, balanced scorecard was created in order to ascertain the compliance by BEE companies. Sectoral BEE charters were also developed for the different segments of the economy (Thornley et al. 2011:4). After revision of the codes by the Minister of Trade and Industry, a deadline of 10 years was determined and certain interim and final targets were also introduced at that stage (Empowerdex 2007:8).

All of the above instruments of BEE have been implemented by government to ensure that before any private institution enters into transactions with the public sector, it must obtain a BEE certificate to ensure its BEE compliance. Only after the obtainment of a BEE certificate can a public-private economic relationship exist in terms of economic transactions (Acemoglu et al. 2007:9). This ensures leverage to the government in certain sectors of the economy (Rumney 2005:410)

\section{Defining Black Economic Empowerment}

Because of its complexity, BEE is not easy to define. There is a risk of defining it too broadly, creating the idea that BEE is only focused on economic development and transformation in general. On the other hand, the risk might be a toonarrow definition, creating the false idea that BEE is only about transferring ownership of corporate assets from white people to black people. Due to this challenge, the following definitions are upheld (DTI 2014:15):

The primary focus of BBBEE is to ensure equal opportunities for all South Africans, especially previously-disadvantaged or -designated groups (Chimhandamba 2008:16). 
The BEE Commission defined BEE as being a socio-economic process within the Reconstruction and Development Programme (RDP) of South Africa, aimed at correcting the imbalances of the past and working toward a transfer of ownership of financial resources to black people (Acemoglu et al. 2007:4).

During 2003, the DTI emphasised that BEE can be seen as a socio-economic process utilised by South African organisations to ensure a diverse workforce and ownership of businesses on micro-level (DTI 2014:16).

The phrase 'black people' can be defined as a term used for Africans, Coloureds and Indians (BEE Act; South Africa 2003, s. 1). The Act further defines BBBEE and categorises women, workers, youth, people with disabilities and people living in rural areas as black people.

The most important BBE objectives are (Chimhandamba 2008:18):

1. Greater black ownership and management of enterprises. Black ownership indicates that at least $51 \%$ of the owners are black people.

2. Increase black ownership and management in priority sectors of the economy.

3. Gain greater access to financial support for BEE.

4. Empowerment of rural communities by enabling them to participate in economic activities.

5. Development of human resources within enterprises by way of education, training, mentorship.

6. Assist by way of expanding the financial and operational spheres of BBE enterprises.

7. Focus specifically on black women, by facilitating them with skills development, infrastructure development and access to economic activities, in order for them to become owners of BEE enterprises.

\section{Elements of Black Economic Empowerment and the generic scorecard}

Firms are evaluated in terms of their BEE compliance. The following seven elements of BEE are taken into account and depict which attributes a private institution on micro-level must encompass in order to be BEE certified. These seven elements, as set out in the Code of Good Practice, are as follows.

\section{Ownership}

The Code of Good Practice (hereafter, 'the Code') provides an element of ownership in terms of BEE. This element ensures that effective ownership by black people is measured when determining the level of BEE compliance by an enterprise via the generic scorecard. Ownership classified as 'broadbased' is regarded as being unencumbered. Pension funds and investment schemes of a collective nature are viewed as part of excluded equity and are part of an organisation, irrespective of the manner in which ownership is measured (DTI 2006:8).

\section{Control}

The Code also provides for the element of managerial control and assesses managerial efficiency of black leaders in enterprises (DTI 2006:9)

\section{Employment equity}

The Code provides for equity, specifying initiatives and the degree to which equity is measured (DTI 2006:9). In terms of employment equity, certain prerequisites must be complied with by participating companies. These include the promotion of non-racial, gender-sensitive workplaces as well as a respectable workplace that provides reasonable work conditions, respect to sustainable development of the environment and cultural diversity (Mathura 2009:47). The Employment Equity Act is the main source of rules, regulations and prerequisites that must be adhered to by companies and is used to develop further involvement by people of colour in participating companies (DTI 2014:30).

\section{Skills development}

The Code provides for elements of skills development and focuses on the development of the competencies of black employees in the different enterprises and the level of training the employers offer their employees (DTI 2006:9). Despite high levels of a low-skilled labour force and low levels of a high-skilled labour force, there is still not enough attention paid to the investment of skills development amongst labourers. To address this problem, BEE requires evaluated companies to instil mentorship programmes within their companies. Companies must provide proof of the submission and implementation of these programmes in their companies and this must be portrayed in their annual BBBEE reports. Non-compliance ensures a score of zero in this category on the generic scorecard (Mathura 2009:47).

\section{Procurement}

The Code provides for the element of Preferential Procurement and indicates the level at which enterprises trade actively with other BEE complying suppliers, as well as black-owned enterprises (DTI 2006:10). The promotion of BEE compliance amongst the suppliers can be done by assessing the supplier in terms of its sectorial charter or the Code and the generic scorecard (Mathura 2009:46). A matrix has been compiled against which procurement from suppliers can be measured (Table 1).

TABLE 1: Procurement Matrix.

\begin{tabular}{lll}
\hline BBBEE status & Qualification & Weighting Recognition (\%) \\
\hline Level 1 & $\geq 100$ points & 135 \\
Level 2 & $\geq 85<100$ & 125 \\
Level 3 & $\geq 75<85$ & 110 \\
Level 4 & $\geq 65<75$ & 100 \\
Level 5 & $\geq 55<65$ & 80 \\
Level 6 & $\geq 45<55$ & 60 \\
Level 7 & $\geq 40<45$ & 50 \\
Level 8 & $\geq 30<40$ & 10 \\
Level 9 & $<30$ & 0 \\
\hline
\end{tabular}

Source: Department of Trade and Industry (DTI), 2006, Construction sector: Broad-based black economic empowerment charter version 6, DTI, Pretoria BBBEE, broad-based black economic empowerment. 
To determine the BBBEE status of a BEE enterprise, a company would be allocated a certain amount of points (Qualification), which would then be converted to a percentage (Weighting Recognition), after which the level of BEE compliance by the company could be determined (BBBEE status). If the ownership of a company exceeds a 50-percentile level, the BBBEE status is determined at a level above the actual calculated scorecard level (DTI 2006:12).

\section{Enterprise development}

The Code provides for the element of Enterprise Development, which is focused on the establishment of a framework for coordinated development amongst smaller to medium enterprises, to ensure the sustainability of BEE companies and to boost levels of ownership transfers amongst black people (Mathura 2009:48). This development can take two forms: investments can be made in black-owned and blackempowered companies or, alternatively, joint ventures can be made with these black-owned and -empowered companies. Joint ventures may constitute the outsourcing of projects by the established company to the black company or both companies can contract for the same projects resulting in a spill-over of skills. How effective these joint ventures are, can be established by determining whether the black company would be able to execute the core elements of the joint project independently, with success and without compromise to its competitiveness (DTI 2014:31).

\section{Corporate Social Investment}

This section of the Code is also referred to as 'the residual' and measures how BEE enterprises contribute to socioeconomic development in their respective sectors. Sectorspecific projects are identified in which the BEE enterprises must participate. Certain guidelines for the evaluation of the projects' outcomes are defined by the Charter Council of each sector. General Corporate Social Investment (CSI) projects can also be developed. These CSI projects may include, for example (DTI 2006:16):

- Development of the community in terms of training and education, for example, adult basic education.

- Provide sector-specific guidance to pupils, for example, in the construction sector, BEE enterprises might focus on science and mathematics skills development.

- Focus on the sustainability of the environment by encouraging communities to grow vegetable gardens and start clean-up initiatives.

- Create HIV and AIDS awareness.

- Sport and health programmes.

- Arts and culture initiatives.

\section{The generic scorecard}

The BBBEE scorecard is utilised to measure a company's level of compliance with BEE. The goal of this evaluation lies in the fact that the score obtained can be used to enhance a BEE enterprise's relationship with government entities in terms of procurement, the establishment of public-private relationships, purchase of state-owned enterprises and any other relevant economic activity (Tucker 2003).
This scorecard can be divided into three main categories and subdivided into another seven subcategories. The seven subcategories are also identified as the seven elements of BEE and its indicators (Burger \& Jafta 2010:9).

The weighting of the elements shows the importance that government attaches to each element and the score of all the elements combined results in a score of 100 points (DTI 2014:34).

\section{Direct empowerment}

Direct empowerment is measured by ownership and management control, and makes up 30 points on the scorecard (Mason \& Watkins 2005:2). The BEE process envisions transfer of ownership to black people, resulting in an increase of control in the economy as a whole. For this to be made possible, black people must obtain assets and enterprises in order to have a controlling interest in the economy. This transfer must be accompanied by an assumption of risk and actual participation in making decisions at both managerial and operational levels. Management control pertains to the right or ability to control votes, appointment or removal of directors and management of shareholders (DTI 2014:30).

\section{Human resource development}

Human resource development is measured by the elements of employment equity and skills development, which forms another 30 points and these elements contribute equally. The expenditure in terms of skills development by an employer is measured as a percentage of the total payroll. Employers must ensure that this expenditure complies with the regulations of the Skills Development Act 97 of 1998 and the Skills Development Levies Act 9 of 1999 (Burger \& Jafta 2010:10).

\section{Indirect empowerment}

Indirect empowerment is represented by procurement (20 points), enterprise development (15 points) and corporate social investment (5 points), totalling the final 40 points (Burger \& Jafta 2010:10). Preferential procurement can assist newcomers to the economic sphere by providing them with opportunities to increase their output.

\section{Policy instruments to achieve Black Economic Empowerment}

In order to achieve the BEE objectives outlined above, government applies certain instruments to ensure the success of BEE endeavours. The main instruments in this case are:

- The BEE Act, which ensures the successful implementation of the BEE Strategy (South Africa 2003, s. 9).

- Specific regulations for the achievement of BEE (DTI 2014:19). Here, the BEE Scorecard can be used as a regulatory means to guide the aforementioned objective.

- Specific procurement targets as well as overall BEE performance targets (DTI 2014:20). 


\section{Impact of Black Economic Empowerment on economic growth}

In this section, a greater focus is placed on theory, forming the basis and rationale for this study. In general, BEE can be linked to economic growth, either positively or negatively, in terms of profitability and competitiveness via the potential linkages between BEE and growth. The first focuses on BEE's effect on property rights and ultimately having an effect on competitiveness of firms, whilst the second focuses on BEE's direct impact on profitability (Acemoglu et al. 2007:16).

\section{Enablers of Black Economic Empowerment}

The first possible benefit of BEE is that there may be an indefinite increase in output of firms participating in BEE activities by hiring black managers. This is because stereotypes of the past, namely, that black people are less productive, are now removed (Acemoglu et al. 2007:20). Efficiency may also increase as a result of newly-appointed black managers completing tasks better than their predecessors. These are only possible and not definite benefits of BEE, clashing with conventional wisdom, but are consistent with the international evidence.

A further benefit of BEE is that the property rights a company obtains can be safeguarded if the company is a BEE participant and fears expropriation. Only BEE-compliant companies are allowed to enter into economic transactions with governmental bodies. This provides a BEE company with a wider preferential business scope in terms of access to government contracts, which may influence their profitability and competitiveness within the South African economic sphere (Acemoglu et al. 2007:20).

BEE companies may also benefit from shareholders that showcase an intrinsic preference to $\mathrm{BEE}$, for example, if the Public Investment Commission is a major shareholder in a company.

Taking all of these benefits into account, there is still no indication of an increase of profitability in the short term; however, long-term effects, such as sustained profitability and an increase in investments, are possible if BEE policies are applied with consistency.

\section{Shortcomings of Black Economic Empowerment}

The first shortcoming of BEE is its possible cost implications. The first cost implication is associated with share transfers to new black owners in BEE enterprises. Shares are often transferred at a discount price below market value. An element of pure transfer exists in these transactions. A pure redistribution of income from existing shareholders to new black owners occurs without having a significant effect on resource allocation. Pure redistribution will not, however, occur if the ownership structure of the company is significant to its profitability. If a transfer of ownership to new black owners causes, for example, difficulty for shareholders with regard to control of the directors, the productivity of the firm may be reduced, leading to a decrease in output and, ultimately, a decrease in profits, eventually lowering the total wealth of everyone in the country (Acemoglu et al. 2007:18).

Another cost implication having an effect on efficiency is where BEE companies lend money to black entrepreneurs to buy shares in a BEE company, because of their lack of wealth. Future dividends are then used to service the loan. Possible payments of higher dividends may result and the ultimate effect will lead to a reduction in investments to below profit maximisation levels (Acemoglu et al. 2007:22).

When BEE companies hire members from this designated group, other cost implications arise. Skills development and training costs are implied, causing output and ultimately profits to decrease because more resources are spent on these incentives, which could have been utilised to directly promote profit (Acemoglu et al. 2007:24).

The BEE Strategy may also have an effect on foreign direct investment (FDI). The common viewpoint is that BEE encourages disinvestment from foreign investors. An annual report by the McKinsley Global Institute (MGI) in 2004, however, indicated that regulatory and restrictive incentives implemented by countries via the framework of their economic policies had little effect on levels of foreign investments (Empowerdex 2005:3). Foreign companies aiming to invest in BEE companies in South Africa are exempt from the BEE Scorecard ownership category, but must still comply with the rest of the scorecard. Because FDI is not discouraged by regulatory incentives, BEE has no significant effect on the levels of FDI. In South Africa specifically, the volatility of the South African rand has a stronger effect on FDI than BEE (Empowerdex 2005:9).

In terms of the ownership element of BEE, a type of passive ownership exists in the form of pension funds and investment schemes, but this form of ownership by black people does not play a significant role in the transformation of the economy. This can actually be a factor disadvantage because of this form of ownership's effect on economic growth in South Africa and leads to a stagnant level of growth within a BEE enterprise (DTI 2006:8).

\section{Funding and sustainability of Black Economic Empowerment}

Government intervention plays a large part in the growth, implementation and sustainability of BEE incentives. BEE has been identified as a so-called 'Big Push'. BEE was conceptualised and aims to reach new levels of wealth, profitability, competitiveness, equality and social welfare for all. The idea is that when targets are reached, the structural composition of BEE enterprises will have changed indefinitely, ensuring that future equity incentives in the labour market will be unnecessary. In a nutshell, this indicates that, in the long run, there will be no need for BEE incentives as black people will be able to empower themselves (DTI 2013:11). 
As the BEE strategy suggests, sustainability is also possible if there is investment in both the financial and intellectual capital of BEE enterprises. To ensure effective investments, an operational capacity within the enterprises must exist; there must be a sense of economic benefit for BEE enterprises and full participation by the black owners and managers (DTI 2014:31).

If a lack of investment in BEE ventures occurs, the effect of BEE would be limited as a result of a lack of financing and BEE will not be implemented on a broad base. South Africa's rate of saving and investment, along with the economic growth and economic climate, are interdependent. This means that BEE must be a part of the overall economic development strategy of South Africa (DTI 2014:23).

The following section reports on the empirical investigations that were conducted during this study.

\section{Research method and design}

In the evaluation of the BEE status of companies, this study utilised the generic scorecard. Jackson, Alessandri and Black (2005:11) state that the fact that companies attained BEE status ensured them a place amongst the top 50 BEE enterprises in South Africa; and the possibility exists that their level of profitability and competitiveness will also be higher. The top 50 were determined by comparing the top BEE enterprises that featured on Empowerdex for three consecutive years (2009, 2010 and 2011). This study formed the hypothesis that companies with high BEE scores reach higher levels of profitability and competitiveness and may therefore attract more investments.

\section{Research design}

A quantitative study was undertaken to find empirical evidence supporting the idea that a high BEE score is associated with higher profitability and competitiveness of companies. Thus far, literature does not link BBBEE compliance to company performance empirically; therefore, this study followed the Abdo and Fisher (2007:45) approach. Their study measured the impact of corporate governance disclosure on financial performance and the same concept of a factual scorecard was used. The scorecard used relates closely to the generic BEE scorecard.

The empirical analyses of the current study were based on data evaluated over three years stretching from January 2009 to December 2011. This time period was selected as it is the most recent data available and relevant to the study. The BEE Scorecard was used to obtain the BEE score of the top 50 BEE companies in South Africa. Hereafter, the top 50 companies' financial information was gathered from their Johannesburg Securities Exchange (JSE) information catalogues.

\section{The Black Economic Empowerment scorecard}

Subjectivity in the determination of BEE scores of the various companies was averted by the application of the
Empowerdex database and information. Empowerdex (2014) is an independent BEE-rating agency that compiles lists of the top 50 BEE companies over a research period. Empowerdex uses information obtained from the companies themselves as well as information that is publicly available, then applies the BEE scorecard to evaluate the companies and determine a BEE score. For the purposes of this study, only the total BEE scores of the applicable companies were used and only information that was publicly available from Empowerdex.

\section{Financial data collection and data management}

Financial information was mainly obtained from financial catalogues, publicly available from the I-Net Bridge website (I-Net Bridge 2014). Information with regard to operating profit, turnover and investment was procured, to be used as independent variables in this study. Empowerdex and I-Net Bridge are authoritative sources, providing the most recent raw data as used in the study.

\section{Sample and unit of analysis}

A sample of 26 of the 50 companies was ultimately used. This might be too small to generalise, but it provides information on the particular companies studied and probably indicates some trends that are emerging. As more data is made available, these findings will become more robust. Companies were excluded from the sample selection of this study if they were:

- not represented in all three years of the analysis

- de-listed during the study

- missing data.

\section{Limitations}

A limitation of this study was that some companies chose to indicate their BEE scores on their websites and only measure and report some of the elements of BEE. It can therefore be assumed that the scores indicated on the websites might not reflect the true level of compliance by these companies. BEE scores are a measure of relative performance by the sample companies and not absolute indications of compliance progress.

\section{Results}

\section{List of samples and ranking of companies}

Table 2 lists and rank the top 50 companies between 2009 and 2011. The number to the left of the company's name is the sample number of that particular company. The number in the last column of the table indicates the ranking of the company in the top 50 list of BEE-compliant companies. Companies that did not appear on the JSE's top 50 company list for three consecutive years were also removed. Only the relevant companies that were used during the study are included in Table 2.

On the BEE scorecard, Standard Bank ranked number one in 2011, followed by Nedbank and Kelly Group Ltd. in the 
TABLE 2: List of samples and ranking of companies.

\begin{tabular}{|c|c|c|c|}
\hline \multirow{2}{*}{ Ranking } & \multicolumn{3}{|c|}{ Top BEE } \\
\hline & 2011 & 2010 & 2009 \\
\hline 1 & 1. Standard Bank of South Africa Ltd & - & 1. Adcorp Holdings \\
\hline 2 & - & 1. Adcorp Holdings Ltd & 2. Hosken Consolidated \\
\hline 3 & 2. Nedbank Ltd & 2. Nedbank Ltd & 3. Nedbank Group \\
\hline 4 & 3. Kelly Group Ltd & 3. Kagiso Media Ltd & 4. Kelly Group \\
\hline 5 & 4. Hosken Consolidated Investments Ltd & 4. Brimstone Investment Corporation Ltd & 5. GijimaAst Group \\
\hline 6 & 5. Adcorp Holdings Ltd & 5. Hosken Consolidated Investments Ltd & 6. Glenrand MIB \\
\hline 7 & 6. Old Mutual plc & 6. Glenrand MIB Ltd & 7. AdaptIT Holdings \\
\hline 8 & - & 7. Firstrand Ltd & 8.Tongaat Hulett \\
\hline 9 & 7. Tongaat Hulett Ltd & 8. Group Five Ltd Basic & - \\
\hline 10 & 8. Kagiso Media Ltd & 9. Kelly Group Ltd & 9. FirstRand \\
\hline 11 & 9. Group Five Ltd & 10. Tongaat Hulett Ltd & 10. Netcare \\
\hline 12 & - & 11. Gijima AST Group Ltd & 11. Primeserv Group \\
\hline 13 & 10. Sun International Ltd & 12. Netcare Ltd & 12. Standard Bank Group \\
\hline 14 & - & 13. Metropolitan Holdings Ltd & - \\
\hline 15 & 11. Brimstone Investment Corporation Ltd & - & 13. Oceana Group \\
\hline 16 & 12. Metropolitan Holdings Ltd & 14. Business Connexion Ltd & - \\
\hline 17 & 13. Oceana Group Ltd & 15. Primeserv Group Ltd & - \\
\hline 18 & - & 16. Standard Bank of South Africa Ltd & 14. Metropolitan Holdings \\
\hline 19 & - & - & 15.Old Mutual Plc \\
\hline 20 & 14. Netcare Ltd & 17. Super Group Ltd & 16. Sun International \\
\hline 21 & - & - & 17. Paracon Holdings \\
\hline 22 & 15. Primeserv Group Ltd & - & 18. Cashbuild \\
\hline 23 & - & 18. AdaptIT Holdings Ltd & - \\
\hline 24 & - & - & - \\
\hline 25 & 16. Allied Electronics Corporation Ltd & - & 19. Business Connexion \\
\hline 26 & - & - & - \\
\hline 27 & 17. AdaptIT Holdings Ltd & - & - \\
\hline 28 & - & - & - \\
\hline 29 & - & - & - \\
\hline 30 & 18. Firstrand Ltd & 19. Sun International Ltd & - \\
\hline 31 & 19. Gijima Holdings (Pty) Ltd & - & - \\
\hline 32 & - & 20. Oceana Group Ltd & 20. Allied Electronics \\
\hline 33 & 20. Paracon Holdings Ltd & 21. Paracon Holdings Ltd & 21. Santam \\
\hline 34 & - & 22. Allied Electronics Corporation Ltd & - \\
\hline 35 & - & - & 22. Super Group \\
\hline 36 & 21. Santam Ltd & 23. Absa Ltd & 23. Kagiso Media \\
\hline 37 & 22. Glenrand MIB Ltd & - & - \\
\hline 38 & - & - & - \\
\hline 39 & - & - & - \\
\hline 40 & - & - & 24. Brimstone Invest \\
\hline 41 & - & 24. Santam Ltd & - \\
\hline 42 & 23. Allied Electronics Ltd & - & 25. Absa Group \\
\hline 43 & 24. Absa Group Ltd & 25. Cashbuild Ltd & - \\
\hline 44 & - & - & 26. Group Five \\
\hline 45 & - & 26. Old Mutual Plc & - \\
\hline 46 & - & - & - \\
\hline 47 & - & - & - \\
\hline 48 & 25. Super Group Ltd & - & - \\
\hline 49 & 26. Business Connexion Ltd & - & - \\
\hline 50 & - & - & - \\
\hline
\end{tabular}

BEE, Black economic empowerment.

second and third places respectively. Adcorp Holdings and Hosken Consolidated Investments Ltd. were also amongst the top three companies during the preceding years, whilst Kagiso Media Ltd., Brimstone Investment Corporation Ltd. and the Gijima Ast Group were also amongst the top five during the period 2009-2011.

In all of the results depicted below, in graph and table format as well as result discussion, only the 2011 data is portrayed.
This is the most recent available data on the subject. In all three consecutive years of the study, 2009-2011, the same trends were evident from analysis. A constant theme in the results for all three years was apparent with only slight changes in the performance of individual companies in the sample size. These changes did not affect the overall theme of the results and therefore only 2011's results are represented, acting as an indicator of the general results of the study. 


\section{Profitability}

When the BEE scores are compared with the operating profit and turnover as elements of profitability, it was found that regardless of the BEE scores, some companies still had high levels of profitability. In fact, sample 26, with the lowest BEE score of all the samples, had the highest level of profitability (Table 4 and Figure 1).

Figure 1 depicts the effect of BEE on profitability and turnover of the 26 sample companies in monetary terms (South African Rand) during 2011. Considering the relationship between BEE score, operating profit and turnover, there does seem to be a high level of correlation. On average, $21.1 \%$ of the variation in the operating profit is explained by variations in BEE scores and $9.9 \%$ by turnover. In all estimates, companies' BEE scores did have an influence on profitability overall. The top three firms were samples 4, 5 and 25 . When comparing these top samples with the list of ranked samples as shown in Table 2, the top three firms whose profitability was increased by BEE are: Hoskens Consolidated Investments Ltd, Adcorp Holdings Ltd and Super Group Ltd. The top three firms whose turnover was increased by BEE are Hoskens Consolidated Investments Ltd, Kagiso Media Ltd and Super Group Ltd.

In all of the regressions estimated, the $R^{2}$ values are very low (on average 6.3\%). The BEE score was the dependant variable

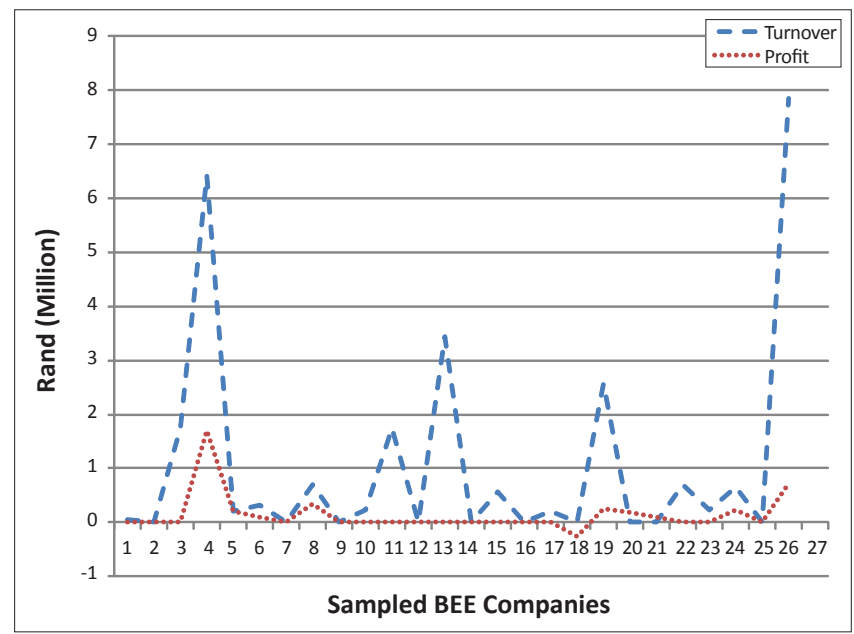

BEE, Black economic empowerment.

FIGURE 1: Black economic empowerment, profit and turnover. and operating profit and turnover the independent variables. Table 3 shows that the same prevails for the standard errors (2011 as illustrated). The values of the probabilities vary.

Although the BEE concept is still too new and data too scarce to generalise, taking the overall information into account, the relationship between BEE score, operating profit and turnover and the effect of BEE score on the profitability of firms seem positive. Based on Tables 1 to 3 , it can be stated that the $p$-values are too high to be statistically significant at a $95 \%$ degree of certainty.

\section{Competitiveness}

As a measure of competitiveness, BEE scores were compared to the level of investment, as a proxy. In terms of competitiveness, it was found that the results are sporadic. All of the companies show a positive relationship between investment and BEE score. There seems, however, to be a slightly lower correlation between investment and BEE scores. The correlation coefficients $\left(R^{2}\right)$ average at $19.8 \%$.

Figure 2 depicts the effect of BEE on investment within firms. At all 26 samples during 2011, a positive relationship exists between levels of investment and BEE within the firms. The top three firms, as indicated on the graph, are: Kagiso Media Ltd, Metropolitan Holdings Ltd and Oceana Group Ltd. When analysing the $R^{2}$ values, which range between $0.97 \%$ and $14.7 \%$, some conclusion can once again be made in terms of the effect of the BEE score on investments (Table 4 and Figure 2). Every year, the statistics seem to vary, but they still show a positive relationship thus far. The variables are correlated and investment levels in the different companies seem to differ in relation to the growth in BEE scores of the companies.

\section{Discussion and conclusion}

The purpose of this study was to determine the effect of $\mathrm{BEE}$ on economic competitiveness, investment and the profitability of firms; to define the challenges associated with BEE; and to place a specific focus on the link to the possible disadvantages that may impair firms' abilities to succeed in their production-related endeavours. Little evidence of the last-mentioned fact was found.

TABLE 3: Black economic empowerment, profit and turnover.

\begin{tabular}{|c|c|c|c|c|}
\hline \multirow[t]{2}{*}{ Variable } & \multicolumn{4}{|c|}{ Dependent Variable: BEE_SCORE2011 } \\
\hline & Coefficient & Std. Error & $t$-Statistic & Probability \\
\hline OPERATING_PROFIT2011 & $4.17 E-06$ & $4.06 \mathrm{E}-06$ & 1.025164 & 0.3159 \\
\hline TURNOVER2011 & $-3.79 \mathrm{E}-07$ & $6.54 \mathrm{E}-07$ & -0.58023 & 0.5674 \\
\hline C & 82.44655 & 1.154746 & 71.39801 & 0 \\
\hline$R^{2}$ & 0.045232 & Mean dependent variance & - & 82.42808 \\
\hline Adjusted $\bar{R}^{2}$ & -0.03779 & S.D. dependent variance & - & 4.976201 \\
\hline S.E. of regression & 5.069357 & Akaike info criterion & - & 6.192472 \\
\hline Sum squared residual & 591.0627 & Schwarz criterion & - & 6.337637 \\
\hline Log likelihood & -77.5021 & Hannan-Quinn criterion & - & 6.234274 \\
\hline$F$-statistic & 0.544816 & Durbin-Watson statistic & - & 0.159014 \\
\hline Prob ( $F$-statistic) & 0.58725 & - & - & - \\
\hline
\end{tabular}

C, intercept; $R^{2}$, coefficient of determination; Prob, probability; S.D., standard deviation; S.E., standard error. 
TABLE 4: Black economic empowerment and Investment.

\begin{tabular}{|c|c|c|c|c|}
\hline \multirow[t]{2}{*}{ Variable } & \multicolumn{4}{|c|}{ Dependent Variable: BEE_SCORE2011 } \\
\hline & Coefficient & Std. Error & $t$-Statistic & Probability \\
\hline INVESTMENT2011 & $9.27 \mathrm{E}-06$ & $1.75 \mathrm{E}-05$ & 0.530009 & 0.601 \\
\hline C & 82.21767 & 1.066867 & 77.06457 & 0 \\
\hline$R^{2}$ & 0.011569 & Mean dependent variance & - & 82.42808 \\
\hline Adjusted $\bar{R}^{2}$ & -0.02962 & S.D. dependent variance & - & 4.976201 \\
\hline S.E. of regression & 5.04935 & Akaike info criterion & - & 6.150199 \\
\hline Sum squared residual & 611.9024 & Schwarz criterion & - & 6.246976 \\
\hline Log likelihood & -77.9526 & Hannan-Quinn criterion & - & 6.178068 \\
\hline$F$-statistic & 0.28091 & Durbin-Watson stat & - & 0.052267 \\
\hline Prob ( $F$-statistic) & 0.600975 & - & - & - \\
\hline
\end{tabular}

C, intercept; $R^{2}$, coefficient of determination; Prob, probability; S.D., standard deviation; S.E., standard error.

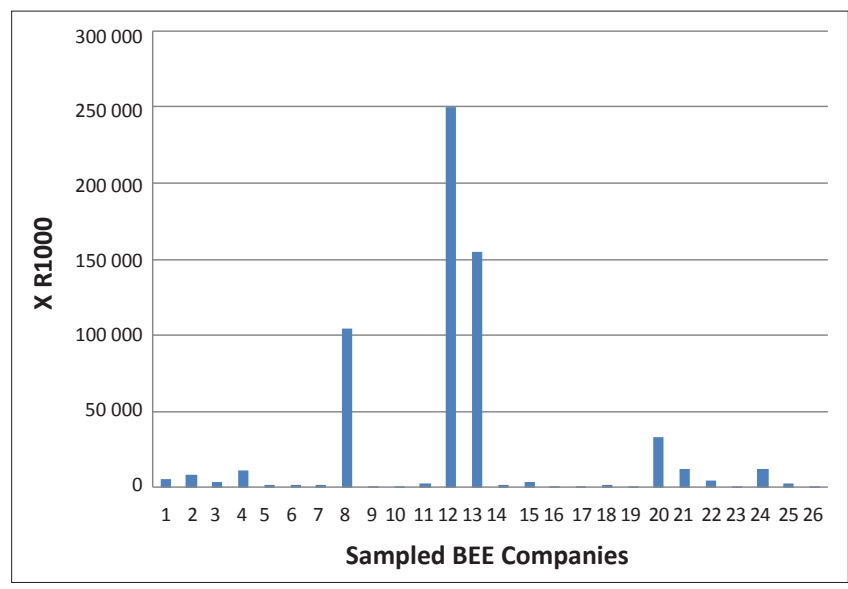

BEE, Black economic empowerment.

FIGURE 2: Black economic empowerment and investment (2011) (Rand x 1000).

When taking into account that the purpose of BEE is the promotion of black economic empowerment and the obligation of the Minister of Trade and Industry to provide the establishment of organs to assist in this study, as stated in the BEE Act (South Africa 2003, Preamble to Act), it can be concluded that the main focus of BEE has a socio-economic motivation. This coincides with the DTI's definition of BEE.

The literature theory suggests that when the enablers of BEE are applied, economic growth is inevitable. The BEE generic scorecard ensures that in order for companies to reap the benefits of high BEE scores, which includes government contracts, active participation in BEE accreditation is compulsory and no form of 'window-dressing' will secure these benefits (Acemoglu et al. 2007:20). The shortcomings of $\mathrm{BEE}$, on the other hand, are related to cost and suggest that the input costs associated with the implementation of BEE outweigh the returns in output.

By taking both the elements of the enablers and shortcomings of BEE into account, a so-called push-pull effect can occur when the positive and negative effects of BEE work against each other, ultimately ensuring that economic growth remains stagnant. Corrective procedures should be implemented in order to ensure change in this effect.

The empirical results indicate that a positive relationship exists between the different BEE Scores and the variables of operating profit, turnover and investment. The top three firms affected positively by BEE do not rank in the top three firms on the sample list in Table 4. These firms are ranked on different levels on the sample list. Kagiso Media Ltd. has been positively affected by BEE and ranks in the top three in the profit and turnover category as well as the investment category. Table 2 correlates with the findings on competitiveness, investment and profits, which were estimated in this study and indicated above.

The conclusion can be made that the effect of BEE in companies thus far has been positive and it is recommended that BEE measures be applied in the future. The years since the implementation of the BEE Act can be regarded as an adjustment phase, where companies had the opportunity to apply the BEE frameworks steadily within their company's policies. This can be regarded as positive developmental growth when considering the socio-economic objective of BEE. On 09 December 2011, a proposed amendment to the 2003 BEE Act was promulgated in the Government Gazette (No. 34809) in order to further reach the developmental goals as set by the Department of Trade and Industry. On 05 October 2012, a revision of the BEE Codes of Good Practice was promulgated in the Government Gazette (No. 35727) in order to aid in achieving the socio-economic objective of BEE. A long-term study in the following years will be needed in order to make further conclusions in this regard, when more available data can be applied.

\section{Acknowledgements}

The authors express their sincere appreciation for the assistance of the external reviewers. Their contribution improved the standard of article considerably.

\section{Competing interests}

The authors declare that they have no financial or personal relationship(s) which may have inappropriately influenced them in writing this article.

\section{Authors' contributions}

The authors worked together doing the analysis, literature study and writing and preparation of the manuscript. M.C.K. (North-West University) formulated the original concept. E.P.J.K. (North-West University) was the project leader, having a Ph.D. in Economics, whilst M.C.K., having both an 
Hons. B.Com Degree in Economics and an LLB, assisted not only in the econometric analysis, but also by giving valuable contributions regarding the legislative aspects.

\section{References}

Abdo, A. \& Fisher, G., 2007, 'The impact of reported corporate governance disclosure on the financial performance of companies listed on the JSE', Investment Analysts Journal 66(3), 43-56.

Acemoglu, D., Gelb, S. \& Robinson J.A. 2007, Black Economic Empowerment and Economic Performance in South Africa, viewed 06 April 2014, from http://www. npc.gov.za/MediaLib/Downloads/Home/Tabs/Diagnostic/Economy2/Black\%20 Economic\%20Empowerment\%20and\%20economic\%20performance\%20in\%20 South\%20Africa.pdf

Andrews, M., 2008, Is Black Economic Empowerment a South African growth catalyst? (Or could it be...), CID Working Paper No. 170, viewed 06 April 2014, from (Or could it be...), CID Working Paper No. 170, viewed 06 April 2014, from
http://www.hks.harvard.edu/var/ezp site/storage/fckeditor/file/pdfs/centershttp://www.hks.harvard.edu/var/ezp_site/storage/fcked
programs/centers/cid/publications/faculty/wp/170.pdf

Antonites, A.J., 2003, 'An action learning approach to entrepreneurial creativity, innovation and opportunity finding', PhD thesis, Dept. of Business Management, Faculty of Economic and Management Sciences, University of Pretoria.

Burger, R. \& Jafta, R., 2010, 'Affirmative action in South Africa: An empirical assessment of the impact on labour market outcomes', CRISE Working Pape No. 76, March, viewed 05 April 2014, from http://r4d.dfid.gov.uk/pdf/outputs/ inequality/workingpaper76.pdf

Chimhandamba, D.G. 2008 'Black Economic Empowerment and Firm Competitiveness', MBA Dissertation, University of Pretoria.

Department of Trade and Industry (DTI), 2006, Construction sector: Broad-based black economic empowerment charter version 6, DTI, Pretoria.

Department of Trade and Industry, 2014, South Africa's economic transformation: A strategy for broad-based black economic empowerment, viewed 25 April 2014, from http://www.dti.gov.za/economic_empowerment/bee-strategy.pdf

Dhanorkar, S., 2010, 'Undoing the past: Black economic empowerment'. Southern African Catholic Bishops' Conference: Parliamentary Liaison Office. Occasiona Paper, 27, viewed 05 April 2014, from file:///C:/Users/Penny/Downloads/OP\%20 $27 \% 20$ Undoing\%20the\%20past\%20Black\%20Economic\%20Empowerment.pdf

Empowerdex, 2005, The effects of Black Economic Empowerment (BEE) on Foreign Direct Investment (FDI), viewed 25 April 2014, http://www.empowerdex.co.za/ Portals/5/docs/BEE\%20and\%20FDI\%20June\%202005.pdf
Empowerdex, 2007, An Empowerdex guide. The codes of good practice, viewed 14 January 2014, from http://www.empowerdex.co.za/portals/5/docs/ empowerdexguide/definitions.pdf

Empowerdex, 2014, Empowerdex research database, viewed 25 April 2014, from http://www.empowerdex.co.za/RESEARCH/tabid/183/Default.aspx

I-Net Bridge, 2014, I-Net Bridge database and information, viewed 25 April 2014 $\mathrm{http}: / /$ www.inetbfa.com/products/our-data/

Jackson, W.E. III, Alessandri, T.M. \& Black, S.S., 2005, 'The price of corporate social responsibility: The case of black economic empowerment transactions in South Africa', Federal Reserve Bank of Atlanta, Working Paper 2005-29.

Labour Market Commission, 1996, Appendix I [Policy framework for Affirmative Action], viewed 25 April 2014, from http://www.polity.org.za/polity/govdocs/ commissions/finsubm.html

Mason, G. \& Watkins, G., 2005, The role of HR in facilitating black economic empowerment, viewed 05 April 2014, from http://www.workinfo.com/free/ downloads/194.htm

Mathura, A., 2009, 'The impact of broad-based black economic empowerment on the financial performance of companies listed on the JSE', Master's research project, Gordon Institute of Business Science, University of Pretoria.

Porter, M.E., 1998, Competitive advantage: Creating and sustaining superior performance, The Free Press, New York, NY.

Rumney, R., 2005, 'Who owns South Africa: an analysis of state and private ownership patterns', in J. Daniel, R. Southall \& J. Lutchman (eds.), The state of the nation: South Africa 2004-2005, pp. 401-422, HSRC Press, Johannesburg.

South Africa, 1998, Employment Equity Act, 55 of 1998, Government Printers, Pretoria.

South Africa, 2003, Broad-Based Black Economic Empowerment Act, 53 of 2003 in Government Gazette No. 25899, Government Printers, Pretoria.

South Africa, 2007, Codes of Good Practice, in Government Gazette No. 29570, Government Printers, Pretoria.

Stiglitz, J., 2006, Making globalisation work, Allen Lane, London.

Thornley, B., Wood, D., Grace, K. \& Sullivant, S., 2011, Impact investing: A framework for policy design and analysis, InSight at Pacific Community Ventures and the Initiative for Responsible Investment, Harvard University.

Tucker, C., 2003, Summary of black economic empowerment in South Africa, Bowman Gilfillan, viewed -5 April 2014, from http://www.bowman.co.za/News-Blog/Blog/ SUMMARY-OF-BLACK-ECONOMIC-EMPOWERMENT-IN-SOUTH-AFRICA 